\title{
Sexual exploitation or legitimate surrogacy: Reading the Hagar narrative (Gn 16:1-4a) in African context
}

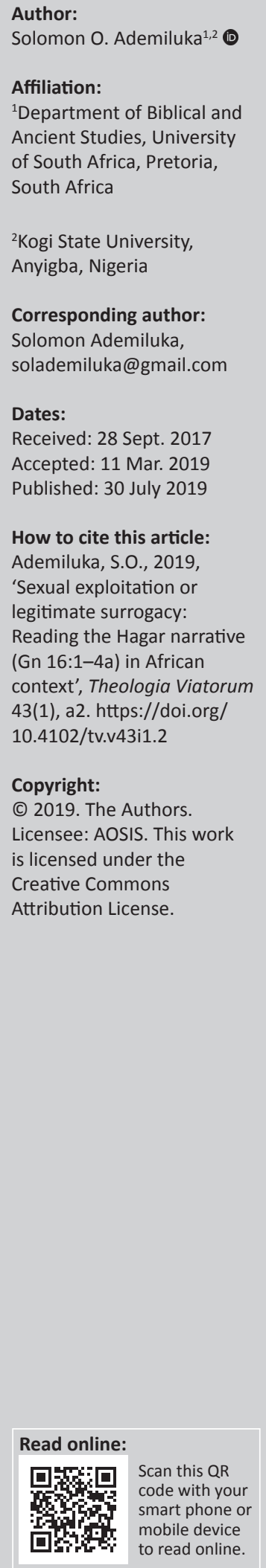

Barren and advanced in age, Sarai proposed to Abram to take her maid, Hagar, as a wife so that they might have children through her. To some interpreters, this is sexual exploitation of Hagar. Using a reader-oriented approach, this article re-examines this mode of interpretation as well as assesses the perspectives in which the Hagar narrative appeals to the African reader. We found out that, when studied against its social background, the Abram-Hagar union is better understood as legitimate surrogacy. The research also found out that the text appeals to the African reader in the contexts of the problem of childlessness and modern surrogacy. The childless African reader thus finds solace in this narrative as it is suggestive of surrogacy as a pragmatic solution to his or her problem.

Keywords: Patriarchal narratives; Childlessness; African culture; Sexual exploitation; Surrogacy.

\section{Introduction}

In Genesis 16:1-4a, ${ }^{1}$ Sarai, ${ }^{2}$ advanced in age and barren, and apparently losing the hope of bearing a child by herself, proposes to Abram, her husband, to take her maid, Hagar, as a wife so that they may raise a family through her, an arrangement to which some scholars have given a sexual exploitation interpretation. Using a reader-oriented approach, this article re-examines this mode of interpretation against the social context of the text. The work also assesses the perspectives in which the Hagar narrative appeals to the African reader, sexually exploitative or otherwise. In order to properly situate our own approach in relation to current scholarship on the patriarchal narratives, the work begins with a review of the findings of the historical-critical method in that section of the Old Testament. Subsequently, the essay examines the nature of Hagar's marriage to Abram, the sexual exploitation claim, the narrative in its social context, and finally its relevance in African context.

\section{The nature of the patriarchal narratives}

The literary analysis of Genesis can be approached in several ways. There is the formula that displays the structure possibly intended by the author of the final form of the text. The phrase תוֹלְדוֹת אַלֶיה [usually translated as 'These are the generations of'] occurs 11 times between 2:4 and 37:2. Except in 2:4 where the phrase is followed by 'the heavens and the earth', in the other instances, it is followed by a personal name. Longman and Dillard opine that following this pattern the book has a prologue followed by 10 episodes (Longman \& Dillard 2006:53). Following the תistichula, Birch et al. identify three basic sections in Genesis 12-50, in which each section 'is introduced by a genealogical formula, which may be found in Genesis 11:27; 25:19; and 37:2' (Birch et al. 2005:62). The three names that appear in the formula are Terah, Isaac and Jacob. Similarly to Longman and Dillard, the authors also believe that 'these markers provide evidence for the way in which the biblical authors and editors understood this material to be organized' (Birch et al. 2005:62).

However, the translation of תis as 'generations' is rather misleading to the modern reader as it gives the impression that the final authors intended to give an account of 10 generations (i.e. eras) between Adam and Jacob (Longman and Dillard recognise 'ten episodes', as noted above). Hence, Gilchrist observes that the common translation of sis as 'generations' is not appropriate in terms of the modern meaning of the word (generation). In relation to people, the term refers to:

$[A] \mathrm{n}$ entire group of people living at the same period of time, or the average length of time that such a

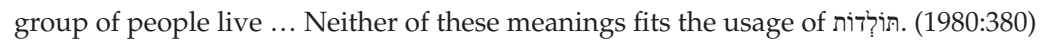

1.Only verses 1-4a are relevant for this work because its focus is on the issue of the marriage of Hagar to Abram

2.'Sarai' and 'Abram' are used as in the text, not 'Sarah' and 'Abraham' as the matriarch and patriarch are respectively known subsequently. 
This point can be illustrated with how תis is used in each of the 11 cases in Genesis. In each of them, the same term is used but not intending the same meaning in all the cases. The word 'origin' or 'account' would be an appropriate translation at 2:4; 'account' or 'story' would be suitable at 6:9; $25: 19$ and $37: 2$, but in each of $5: 1 ; 10: 1 ; 11: 10$ and $11: 27$ 'genealogy' is the most suitable word. Some dictionaries (e.g. Feyerabend 1959:368) rightly recognise the fact that the word תis is capable of several meanings, such as 'origin', 'genealogy', 'family register' and 'lineage'.

Another approach to the literary analysis of Genesis focusses on its content and genre. Following this approach, scholars recognise two sections, namely 1:1-11:32 and 12:1-50:26. The former is the primeval history and covers the time between creation and the tower of Babel whereas the second part is the so-called patriarchal narratives which focus on the stories about Abraham and his descendants from the time he entered into Canaan and the time of the death of Joseph in Egypt. The second part is further subdivided between the patriarchal narratives (12-36) and the Joseph story (37-50) (Birch et al. 2005:64; Longman \& Dillard 2006:53; Moore \& Kelle 2011:43).

The patriarchal narratives record concerns dealing with private family affairs, as against public ones; issues such as 'birth and death, family disputes, grazing and burial rights ...' (Wenham 1994:54). This, according to Wenham, proves that for the writer of Genesis these individuals were real historical figures, and not personifications of clans or the products of his imagination as some scholars claim. Perhaps viewing the narratives from this perspective, during the first half of the 20th century, there arose a scholarly consensus that placed 'the ancestors of the Israelites in a historical setting' (Matthews 2002:3). The Albright school (particularly following Albright's 1961 article) tenaciously promoted the idea that 'the patriarchal traditions contained substantial history' (Grabbe 2007:52). According to Bright, for example, the patriarchal stories fit authentically in the milieu of the second millennium BCE, between the 16th and 17th centuries, even though he affirmed lack of 'evidence to fix the patriarchs in any particular centuries' (Bright 1981, cited by Grabbe 2007:53). Hence for many, the era of the so-called patriarchs was the logical place to begin the history of ancient Israel (Moore \& Kelle 2011:43). To this end, many introductions to the Old Testament and histories of ancient Israel produced in the mid-20th century 'routinely equated Genesis $12-50$ with a historical period, the so-called Middle Bronze Age, ca. 1800-1600 BCE' (Birch et al. 2005:61).

To support this position, in the 19th and early 20th centuries, scholars sought extrabiblical evidence in the ancient Near East (Moore \& Kelle 2011:43). In this regard, the Albright school claimed that the names of the patriarchs are names that were frequently used in the early second millennium BCE. Names such as Jacob, Isaac and Ishmael were said to be found among the early Amorites (c. 1800 BCE). Other names like Serug, Nahor and Terah were also claimed to be attested in the area of Haran, which would confirm that the patriarchs came from there as indicated in Genesis 12 (Bright 1981:77; Wenham 1994:54). Albright and his followers also argued that texts from the second millennium cultures at Nuzi and Mari reflected social customs and legal practices parallel with those in the patriarchal narratives (Moore \& Kelle 2011:51; cf. Bright 1981:79). For example, in the Nuzi texts, these historians claimed to find adoptions of slaves by childless couples, which they said were a parallel to Abraham's adoption of Eliezer (Gen 15) (Moore \& Kelle 2011:51). Thus:

By mid-twentieth century, virtually all historians, especially Americans, held that archaeological data substantiated the general plotline of the biblical stories and events, and placed the patriarchs in the Middle Bronze Age (2000-1500). (p. 49)

However, beginning from the 1970s, critical scholarship started to re-examine this consensus, in which the works of two scholars are regarded notable, namely Thomas L. Thompson (1974) and John Van Seters (1975). In the first place, they affirmed that the only information preserved concerning the so-called patriarchal age was what could be found in the text of Genesis; 'there was no direct external confirmation, either epigraphic or literary' (Grabbe 2007:52). As Matthews puts it, 'To date, no extra biblical direct mention of any of the ancestors has come to light' (2002:4). Also rejected by scholars was the use of the names of Abraham's relatives to prove the historicity of the narratives, contending that names such as Serug, Nahor, Terah, and Haran were not names of individuals but those of 'several villages and a city in the region of Mesopotamia' (Noll 2013:6; cf. Grabbe 2007:54). Thompson (cited by Moore \& Kelle 2011) argued against the antiquity and uniqueness of west semitic personal names in the patriarchal stories, stating that they are not limited to the Middle Bronze Age but appear 'all the way down into the Neo-Assyrian period of ancient history (ca. 900-612)' (Moore \& Kelle 2011:58).

Thompson and Van Seters (cited by Moore \& Kelle 2011:56-63) particularly questioned the so-called parallels claimed to link the patriarchal narratives to the early second millennium, and their supposed affinity to ancient Near Eastern texts (Moore \& Kelle 2011: 57). The majority of the social customs claimed to indicate a second millennium date for the patriarchal traditions appeared in many periods, including even the first millennium. For example, the practice of a barren wife providing a female slave to her husband (cf. Gn 16) is said to appear 'not only in Nuzi texts from the Middle Bronze Age but also in Assyrian writings from the seventh century BCE' (Moore \& Kelle 2011:59). Grabbe contends that many of the Nuzi customs are actually not parallel to those in Genesis; the supporters of the parallel-customs hypothesis misunderstood or misrepresented either the Nuzi text or the biblical text. 
For example, according to Grabbe, the Genesis version of the adoption of Eliezer was contrary to the Nuzi custom:

In the end, none of the alleged customs demonstrating an early second millennium background for the patriarchal stories seems to have stood up ... [hence] the biblical text is eliminated as having little to tell us about the second millennium BCE ... (Grabbe 2007:55, 64).

Critics in the 20th century also pointed out a number of anachronisms in the patriarchal narratives which would witness against a background of early second millennium for these stories. Among other things, the critics made reference to the mention of camels (Gn 12:16; 24:10; 30:43), which were widely used in the ancient Near East but only in the late second millennium (cf. Gn 12:16; 24:10; 30:43) (Moore \& Kelle 2011:60). In this way, critical scholarship concluded that the alleged pieces of evidence from the ancient Near East could prove neither a second millennium date for the patriarchal narratives, nor the historicity of the text itself. This conclusion invited interpreters to seek alternative methods 'of engaging the nature and function of the Genesis stories' (Moore \& Kelle 2011:45). In the wake of Wellhausen (1994), Hermann Gunkel (1901) and his followers identified a long, preliterary stage for the patriarchal stories during which they were transmitted orally as sagas (Ademiluka 2007:273-282; Birch et al. 2005:65; Longman \& Dillard 2006:55; Moore \& Kelle 2011:47). Hence, 'any historical elements of the patriarchal stories were hidden behind the legendary and literary character of the narratives' (Moore \& Kelle 2011:47). One logical outgrowth of the form-critical approach to Genesis is tradition history, commonly associated with the works of Martin Noth (1950). Noth argued that the individual stories in Genesis were told at particular sites, such as Beersheba and Bethel, and later (Birch et al 2005):

[C]ollected and then developed into the literary configuration in which we currently have them ... Noth presumed that what were originally unrelated characters -Abraham, Isaac, and Jacob - were later connected by means of a fictive genealogy. (p. 66)

Similarly, Gertz et al. state that there is a consensus in scholarship that the originally individual traditions concerning the three patriarchs and the corresponding matriarchs 'were only later assembled and connected with one another through genealogy and geography' (2012:335). According to them, the purpose of this was to provide a justification for the existence of Israel on the land. Hence, the narratives reflect the relationships with the neighbouring nations such as Moab, Ammon, Edom and Aram. The genealogy and geography were theologised with the introduction of Yahweh, who became the national deity of both Judah and Israel. Therefore, as Wellhausen (1994) had long noted:

$[I] \mathrm{t}$ can be concluded that the ancestral stories generally narrate the history of Israel's origins from the perspective of the period of the nation's existence ...; [in other words, they] are in their core projections back from the period of national existence. (Gertz et al. 2012:335)
However, Van Seters, by reformulating Wellhausen's earlier sources of the Pentateuch, argued that some of the patriarchal traditions, such as Abraham in Egypt (Gn 12:10-20), Hagar's flight (16:1-12) and the birth of Isaac (21), were formulated in the exilic period to encourage the exiles to have faith in the certainty of Yahweh's promises to his people (Moore \& Kelle 2011:60).

Thus, Albrecht Alt (1966) and Martin Noth (1950) concluded that the patriarchal narratives may provide certain information on Israel's early ancestors, but 'nothing specific could be known about the patriarchs as individuals, as we cannot get behind the various stages of oral and literary development in the texts' (Moore \& Kelle 2011:52). On account of these uncertainties, Matthews (2002) expresses doubts if:

[T]he patriarchs, as well as their wives and children, were real persons. They are shadowy figures as far as historians are concerned and may be composites of several persons or tribal leaders ... (p. 3)

On the basis of the foregoing survey, for many historians since the 1970s, 'the patriarchal traditions originated in the Iron Age, and the patriarchs were best understood not as historical figures but as literary creations of this later period' (Moore \& Kelle 2011:61).

However, the general rejection of the historicity of the patriarchal narratives has led some scholars to consider 'how these texts may present truth in a way that is not bound to historicity and ... continue to be meaningful for modern persons today' (Moore \& Kelle 2011:63). The relevance of the Genesis narratives for the modern reader lies in the fact that 'the stories involve fathers and mothers, sons and daughters, aunts and uncles - simply put, families' (Birch et al. 2005:62). That is to say, Genesis $12-36$ presents the story of a family: Abraham, Isaac, and Jacob are grandfather, father, and son, respectively. The individual episodes relate familial fundamental issues such as 'courtship and wedding $(24,29)$, the birth of sons $(16,21,25,29-30)$, as well as jealousy and conflict within the family (13, 16, 29-31), including confrontation about inheritance' (Gertz et al. 2012:333). Hence, Birch et al. (2005) rightly observe that:

As in the case of the psalms and the primeval history, the authority of the text in these family stories does not derive from its role as reporter of either events or history. Instead, the text presents poetry and prose that later religious communities have found not only useful but essential for thinking about their own lives. (p. 62)

In this way, perspectives about the patriarchal narratives have broadened to embrace issues of daily life, because the 1970s scholars have investigated the various indicators of social life revealed in the stories, 'recognizing ... that they may still provide valuable insights into dimensions of communal, family, and personal life' (Moore \& Kelle 2011:69). According to Longman and Dillard, this interpretive style was developed particularly in the 1980s and 1990s in the 
so-called recent literary approach which reemphasises the literary quality of 'the biblical narrative, and in particular the narratives of the book of Genesis', paying less attention to questions of historical reference (2006:40). In this regard, some scholars have called attention to the literary unity and artistic brilliance in the book of Genesis irrespective of its historical importance. Using this literary approach, some interpreters, according to Moore and Kelle (2011):

$[O]$ ffer a theological and reader-oriented engagement with the figures of the patriarchs as literary characters, seeking to explore the theological issues that centre around these characters. [Others] have also fostered an increased awareness of the ways in which the patriarchal narratives portray family dynamics and relationships ... among husbands, wives, fathers, mothers, and children. (pp. 73-74)

Hence, the present work is a reader-oriented engagement with the patriarchal narratives; it examines the problem of childlessness in the family of Abram, exploring the perspectives from which the story of the marriage of Hagar to Abram would appeal to the African reader. However, interpreting the narrative in the African context in this way is the subject of a later part of the work; for now we shall have a close look at the text, beginning with an examination of the nature of the marriage between Abram and Hagar.

\section{The marriage of Hagar to Abram (Gn 16:1-4a)}

Sarai was barren, and desiring to have children, she offered

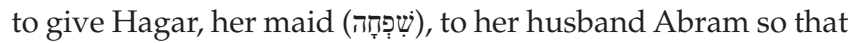
she (Sarai) 'shall obtain children by her' (v. 2, RSV). שְִָׁחָה means 'maidservant' or 'maid' but could also have a wider use of female slave. It is often used indistinguishably and interchangeably with wָזָז, which some English versions also translate as 'maidservant' or 'female slave' (cf. 1 Sm 1:16, 18; Gn 30:3-4). שִשְפָָה was a slave who could be given as a gift to a daughter when she was being given out in marriage (Gn 29:24,29). She could as well be a gift presented to another person as Pharaoh presented gifts to Abram, including maidservants (Austel 1980:946; Scott 1980:49).

Abram agreed to the proposal and took Hagar 'as a wife. And he went in to Hagar and she conceived ...' (vv. 3-4a). In verse 1, Hagar is introduced as an Egyptian (even though the name is Semitic, not Egyptian [Webber 1994:206]). The narrator does not say how Sarai came by her slave but some suggest that Hagar might have been 'one of those she obtained from Egypt' (Jamieson 2018:online). It is possible that 'Hagar was Sarai's slave in Pharaoh's harem' (Roth 2016:online; cf. Gn 12:16, 20). There are conjectures on the status of Hagar, as to whether she was a wife or concubine to Abram. In view of Hagar's status as a slave, a personal property to Sarai, Jamieson opines that the word 'wife' 'is here used to describe an inferior ... relation' (Jamieson 2018:online); hence Hagar was Abram's secondary wife. Similarly, Roth views Hagar as a 'secondary wife or concubine' to Abram (Roth 2016:online). It should be noted that the Hebrew word used to describe
Hagar as wife (v. 3) is w̦ which is the same word for 'woman' and 'frequently used in the sense of wife' in the Old Testament (McComiskey 1980:60). Adamo observes that a majority of the English versions use 'wife' in Genesis 16:3, apart from a few such as the New American Bible and the Catholic Study Bible, which render it as 'concubine'. He, however, notes that translating the word as concubine cannot be appropriate because there is another word for concubine,

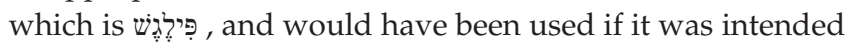
(Adamo 2005:465). This position could be buttressed with the status of the Levite's concubine in Judges 19. In Judges 19:1, 27 the word w is used for the concubine but immediately qualified with author of Genesis 16 thought of Hagar as a concubine but as a wife in a polygamous ${ }^{3}$ setting. In that case, the view of Hagar as a secondary wife would be correct.

As earlier mentioned, part of the aim of this work is to reappraise the view of some interpreters that the marriage of Hagar to Abram is part of the sexual exploitation in the Hebrew Bible; hence in the next section, we shall examine this mode of interpretation.

\section{The sexual exploitation interpretation}

For some scholars, particularly feminists, the giving of Hagar to Abram for marriage, just like the cases of Bilhah and Zilpah (Gn 30), is another instance of the sexual abuse of women in the Hebrew Bible. According to Graybill (2018):

$[I] \mathrm{t}$ is not only the explicit narratives of rape that represent rape culture in the biblical text. Instead, rape culture as a category forces us to look beyond single events to larger conditions of culture. Consider, for example, the theme of the 'barren matriarchs' in Genesis. The use of slave women (Hagar, Zilpah, Bilhah) for the matriarchs is often discussed as a kind of surrogacy. And yet it is equally possible to read these narratives as stories about the sexual exploitation of slaves. (online)

In the opinion of Joseph (2017), Hagar and the other handmaids in Genesis were used as sex slaves, and this highlights 'the sexual values inherent in the Hebrew Bible. Women had no control over their own sexuality; a woman's sexuality belongs to the men in her life' (Joseph 2017:online). Joseph sees the stories of Hagar and the other handmaids as replicated in the Hulu show titled 'A Handmaid's Tale', which was based on Margaret Atwood's novel of the same title, written in 1985. The show 'depicts a dystopian society in which women are taken from their families and enslaved as handmaids to address an infertility problem in the United States' (Joseph 2017:online), thus sharing with Genesis the motifs of barrenness and the use of slave-girls as birth surrogates. Others maintain that Hagar's experience qualifies as rape in that she seems to have no choice as her voice is not heard at all. According to Freyhauf (2012), for example:

3.Technically the term 'polygamy' means marrying 'many' (wives, husbands or times) In this work, it is used in the popular usage of the state of marriage in which there is one husband and two or more wives, which should strictly be 'polygyny', as against one husband and two or more wives, which should strictly be 'polygyny', as against
'polyandry', which refers to a state of one woman marrying two or more husbands (Mbiti 1969:142). 
In Hagar we have an Egyptian slave woman ... forced to engage into sex with her owner's husband for producing an heir. By forcing Hagar to have sexual intercourse with Abram, Sarai asserts ownership over Hagar's womb. Hagar had no choice. She was powerless. She had to obey Sarai. (Freyhauf 2012:online)

Several others emphasise the fact that Hagar's consent was not sought in the decision to make her submit to Abram for sex. Weems (2005) points out that 'the slave Hagar was never asked her opinion' (Weems 2005:online). Religious Tolerance (2018) similarly states that in view of her status as a slave, the decision for Abram to engage in sexual intercourse with Hagar was taken presumably without her consent; in the society of the day 'she was required to submit to multiple rapes at her owner's command' (Religious Tolerance 2018:online). God's Design - Perth (2016) states categorically:

Let us make no bones about it - we would call this rape today. Hagar's situation did not give her the option of saying no, [which makes] her a victim of sexual exploitation. (God's Design - Perth 2016:online)

Thus, like the other maids in Genesis, Hagar was simply 'raped for the sake of nation-building' (Joseph 2017:online). Abram's progeny was more valuable to him than Hagar's abuse (Freyhauf 2012). The fact that Hagar became Abram's wife meant little in terms of her status as slave; 'with the implication that her mistress's husband will now begin having sex with her ... [it was just] a transfer of property' (McGrath 2012:online), that is from Sarai to Abram.

To God's Design - Perth, perhaps Hagar's experience means more than rape:

Hagar's situation meets the definition of sex trafficking. For an adult, the United Nations definition of human trafficking is 'the recruitment, transportation, transfer, harbouring, or receipt of persons by improper means (such as force, abduction, fraud, or coercion) for an improper purpose including forced labour or sexual exploitation'. (God's Design - Perth 2016:online)

For the writer, this definition applies to Hagar's situation. Hagar was a victim of human trafficking because she was a slave, received as a slave by Abram 'in Egypt, transported out of Egypt and harboured in his home as a slave' (God's Design - Perth 2016:online). Hagar was required by her owner to have sex with her master, and there is no indication that her consent was sought for it; thus she was a victim of sex trafficking (God's Design - Perth 2016). Another author similarly empathises with Hagar as one who suffered forced sex and slavery together:

[Although] slavery was - during that time - a perfectly legal and socially acceptable institution ... for a woman to force another woman into sexual slavery in order to serve as her personal 'human incubator' seems cruel beyond belief. (Sex, Slavery and Surrogacy 2009:online)

Thus, to these interpreters the marriage of Hagar to Abram was an avenue for sexual exploitation. As a reappraisal of this mode of interpretation of the text, in the following section we shall examine the social background of the Hagar narrative with a view to getting an insight into the possible manner in which the story was understood by its immediate audience.

\section{Understanding the marriage of Hagar to Abram in its social context}

We begin the section by examining closely the meaning of Sarah's action in giving Hagar to her Abram. As seen earlier, her hope was that 'I may obtain children by her'. The Hebrew phrase which several English versions thus translate is

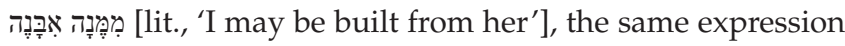

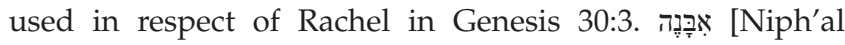
imperfect, 1cs] is from the verb בָָָּ [to build], usually used in reference to houses, cities, towers, altars, etc. It is also used idiomatically as in Genesis 16:2 to mean 'to bring about increase in offspring' (Waltke 1994:116). The idea being conveyed here therefore 'is that of the building up of a house' (i.e. household or family) (Cambridge Bible for Schools and Colleges, in Bible Hub on Gn 16:2:online). In other words, it is by bearing children that a woman builds up a family (John Gill, in Bible Hubon Gn 16:2:online; cf. Rt 4:11). Thus, by giving her maid to Abram, Sarai hoped to raise children by her, thereby building a family.

The wording of the verse seems to reflect the pain with which Sarai took the decision to surrender her husband to another woman for a sexual relationship: ' ... the Lord has prevented me from bearing children. Go in to my servant; it may be that I shall obtain children by her'. Sarai had lost all hope of bearing a child by herself; hence this decision was her last resort to get a child. And in those words the narrator reveals the emotional situation of a barren Hebrew woman. This fact is buttressed in the Benson Commentary when it says that:

$[T]$ he Hebrew women considered barrenness as one of the greatest misfortunes that could befall them, not only from a natural desire of children, but from their eager wishes to be the means of fulfilling the promise to Abraham, and bringing forth that seed in which all the families of the earth were to be blessed. (in Bible Hub on Gn 30:1:online)

From this expression one gets further insight into Sarai's desperation, the desperation which also echoes from other barren women in the Old Testament. For example, 'Rachel preferred death to childlessness' (Encyclopaedia Judaica 2008:online) when she demanded that Jacob should 'Give me children, or else I die' (Gn 30:1). In its exposition on this verse, Ellicott's Commentary informs that barrenness was a great affliction to a Hebrew woman; in fact, 'there is an Oriental proverb that a childless person is as good as dead' (in Bible Hub on Gn 30:1:online). Commenting on the same verse, Jamieson asserts that being a mother 'confers a high degree of honor in the East, and the want of that status is felt as a stigma and deplored as a grievous calamity' (in Bible Hub on Gn 30:1:online). Another example is Hannah who suffered provocation and upbraiding continually from her rival, Peninnah, on 
account of her (Hannah's) barrenness (John Gill in Bible Hub on 1 Sm 1:6-7:online). The Pulpit Commentary states:

Hannah is so sorely vexed at the taunts of her rival that she weeps from sheer vexation. [For Hannah], the husband really is not 'better than ten sons' [1 Sam 1:8] for the joy of motherhood is quite distinct from that of conjugal affection, and especially to a Hebrew woman, who had special hopes from which she was cut off by barrenness. (in Bible Hub on 1 Sm 1:6-7:online)

Hence, contrary to the sexual exploitation view, Abram and especially Sarai were being driven by the desire to have children. It is noteworthy that there are a few cases of rape in the Hebrew Bible and none exhibits the desire of having a child on the part of the rapists as their motive. We may take, for example, Dinah's experience with Shechem in Genesis 34. Although some see it as consensual premarital sex in which case her experience is 'a doomed love story' (Graybill 2018:online), for Klopper, Dinah's encounter with Shechem is 'a classic case of acquaintance, or date rape' (2010:658). In the narrative of Amnon and Tamar (1 Sm 13:1-22), Amnon became infatuated towards Tamar so much that he desired to have sex with her, and in connivance with Jonadab developed a trick to get Tamar. After raping his sister, Amnon was disgusted with her, as it is sometimes characteristic of rapists to 'become enraged after the act because they see their own weakness in their victims' (Mann 2011:203). Thus, for Amnon, Tamar was nothing more than a sex object. In 2 Samuel 16:21-22, Absalom violated his father's concubines as part of the power struggle between them, as in the ancient world 'taking of the wives of the predecessor was a part of the succession' (Smith 2018:online). Unlike the case of Abram and Hagar, in all of the cases just mentioned, the drive of the rapists was pleasure; none involves the issue of barrenness and the desire for children.

Moreover, by the standard of the ancient Near Eastern customs, the union of Abram and Hagar was a marriage properly constituted. In that society:

In the Code of Hammurabi if a man's wife was childless, he was allowed to take a concubine and bring her into his house, but he was not to place her upon an equal footing with the wife. Or, the wife might give her husband a maidservant (amtu). (Cambridge Bible for Schools and Colleges, in Bible Hub on Gn 16:2:online)

Many writers support the view that Sarai and Abram's action was a common and acceptable practice 'in ancient Near Eastern family law' (Fletcher 2006:online). As Roth (2016) puts it, 'Sarai decided to follow the ancient Near East custom of building a family through her husband and servant' (Roth 2016:online). In that custom, 'if your wife cannot have children, you can have children by your wife's slaves, and the child becomes yours' (Bach, cited by Klein 2008:online). In the view of Wenham, according to this custom, Sarah's action was a resort to surrogate marriage. He states:

Surrogate marriage was a well-recognised practice in the ancient Near East for childless couples. A wife would supply her husband with a girl, perhaps one of her maids if she were wealthy, for her husband to have intercourse with. The child when born would count as the wife's child. This practice is assumed in the story of Sarah and Hagar in Genesis 16. (Wenham 2006; cf. Wenham 1994:72)

From the foregoing, describing the marriage of Hagar to Abram as sexual exploitation fails to take due cognisance of the social context of the narrative; it may also have arisen from reading modern meanings to the story. Hence, commenting on the Hagar narrative as reflecting surrogacy, Wenham further states that:

$[W]$ hat we really need to establish is whether these actions contravene biblical law on the one hand or the ethics of the narrator on the other. We must endeavour to avoid reading into the text our own prejudices, and let it speak for itself. (Wenham 2006)

Thus, rather than sexual exploitation, the marriage of Hagar to Abram is better understood as a legitimate employment of surrogacy to solve the problem of childlessness. To the African reader, the story is relevant in the context of the dilemma of childlessness and the various ways of seeking solution to this problem. Hence, in the section below, we examine the Hagar narrative in light of the desire for children in African culture, and as a suggestion of surrogacy as a pragmatic solution to barrenness in Africa.

\section{The Hagar narrative in the context of the problem of childlessness in Africa}

\section{The Hagar narrative in light of the desire for children in African culture}

As it was among the Hebrews, in Africa there is a strong desire for children, so much so that marriage is constituted primarily for the purpose of procreation. Unlike in western society where marriage is person-oriented, 'that is, the concept of marriage as companionship', in the traditional African setting, marriage is fertility-oriented (Emenusiobi 2013:online). It is the union of a man and a woman as husband and wife principally for procreation; hence, without children, marriage is incomplete (Mbiti 1969:133). In Africa 'the sense of children ... as a value to be desired - is so strong' that it overrides other purposes of marriage such as compatibility (Marriage and Family in Africa 1988:online). In fact, in the traditional setting:

[T] he indissolubility of marriage is conditioned to its fruitfulness. Practically speaking, the birth of a child marked the 'consummation' of the marriage. Once a child has been born the marriage is indissoluble. ... Children became a real external sign of this indissoluble unity. (Marriage and Family 1988:online)

In African culture, it is unthinkable for one to die without having children; it means to 'be completely cut off from the human society, to become an outcast and to lose all links with mankind' (Mbiti 1969:133). Among the Igbo of southeastern Nigeria, for example:

For an Igbo man to die childless or without a male child is a calamity; it is tantamount to a descent into oblivion, to be forgotten by both the living and the dead. He has left no one to 
pour libation for him. He is not admitted into the status of an Igbo ancestor after his death, which requires one to have children. (Abasili 2011:567)

Hence, in Africa, marriage is not voluntary but mandatory; 'everybody must get married and bear children: that is the greatest hope and expectation of the individual for himself and of the community for the individual' (Mbiti 1969:133). Deliberate refusal to get married is an abomination; in some societies 'he who does not participate in marriage is a curse to the community' (Emenusiobi 2013:online; cf. Abasili 2011:558). This is why to date every African feels incomplete until he or she gets married and bears children (Emenusiobi 2013:online).

Childlessness is oftentimes a woeful situation, especially for the woman. As was in ancient Israel, it is the dream of every woman to become a mother. A woman's inability to achieve this mother-status can be really calamitous, as it affects both her personality and social status. In many societies, such a woman is looked upon as a social misfit; 'she is openly ridiculed and told that she is not a woman' (Abasili 2011:562). In some other places, 'women often are ostracized as witches or social outcasts if they cannot have children' (NBCNEWS 2018:online). In the past, it was as if a barren woman deliberately refused to:

[G]ive her husband children, [so] she was considered to have failed him - and society - in the most serious way possible. And if he chose to consider his marriage null and send her back to her family, society - and the woman herself - would agree. (Marriage and Family 1988:online)

Even today, a woman faces the risk of divorce if she does not have children. Where a couple has the challenge of childlessness and it is the husband that is (Mbiti 1969):

Impotent or sterile, his 'brother' [i.e. kinsman] can perform the sexual duties and fertilize the wife for him ... but if the wife has no children, or [bears] only daughters, it follows almost without exception that her husband will add another wife. (pp. 143, 145)

Thus, an African woman may lose her marriage not only for not having children but also if she has only female children (cf. Abasili 2011:562; Bvukutwa 2014:online). The traditional explanation for this attitude is that whereas the male child is looked upon as the sustainer of the lineage, girls are 'perceived as expendable commodities who will eventually be married out to other families to procreate and ensure the survival of the spouses' linage by bearing sons' (IgbelinaIgbokwe 2013:online). Igbelina-Igbokwe (2013) further explains that:

Oftentimes, men sought to take second wives because of their first wife's inability to bear an heir. Therefore a woman with no sons is plagued with social insecurity as she lives in constant fear of losing her marriage and her homestead to another who may be brought in to correct her 'inadequacies'. (online)

From the foregoing, in the African context, contrary to the suggestion that Hagar was a victim of rape or sex trafficking, she is understood as a second wife Abram had to marry on account of Sarai's inability to bear him an heir. In Africa, Sarai's suggestion to Abram to go in to Hagar is understood in the context of a barren wife suggesting to her husband to take a second wife. That really used to be the case in the traditional setting; the women were so used to a polygamous situation that at times the first wife would ask 'her husband to take a second wife' particularly as that would mean an additional hand in the family work such as farming (Marriage and Family:online; cf. Mbiti 1969:134).

Thus, the easiest approach open to the traditional African man to arrest the problem of childlessness is the resort to polygamy. In the modern times, whereas barren women seek divine intervention in 'prayer houses' and 'miracle centres' or from traditional healers and orthodox practitioners, their husbands most often take other wives to remedy the problem of childlessness (Abasili 2011:566). In this way, polygamy becomes a necessity in the context of the desire for children. It is important to mention that, apart from solving the problem of childlessness, in the traditional African society, polygamy was also 'esteemed because it ensured a large progeny ... [as] children meant wealth, prestige and the blessings of God and the ancestors' (Emenusiobi 2013:online). Similar to marrying several wives, the desire for children also manifests in other forms of unions, although most of them are no longer common in view of Christianity and Western civilisation. In this regard, there used to be levirate marriage whereby a man 'produced' children for his late kinsman by marrying the latter's widow (Ademiluka 2003:138; Emenusiobi 2013:online; Mbiti 1969:134). Some societies had surrogate marriages where a man married one of the sisters of his late wife who died without children (Mbiti 1969:144; Oshadare et al. 2005:78).

However, the modern African reader of the Bible gets an insight from the story of Hagar that a man need not accumulate women to get children. As mentioned earlier, the Hagar experience is better understood as an employment of surrogacy rather than as sexual exploitation. Hence, in the following section, we examine the Hagar narrative as a suggestion of surrogacy in Africa.

\section{The Hagar narrative as a suggestion of surrogacy in Africa}

According to Umeora et al. (2014), the term 'surrogacy' derived from the Latin word subrogare, which means 'to substitute'. Surrogacy is defined as 'a method or agreement whereby a woman agrees to carry a pregnancy for another person or persons, who will become the newborn child's parent(s) after birth' (Wikipedia Contributors 2018:online). As Umeora et al. put it:

Surrogacy refers to a situation whereby a third party female elects or is commissioned to carry a pregnancy on behalf of another couple, delivers a baby and hands the child over to the commissioning parents at birth. (Umeora et al 2014:online)

Certain conditions can make a couple to seek a surrogacy arrangement, such as when pregnancy fails to happen for 
whatever reasons, or when it constitutes a risk for the intended mother. It may also be the man that is infertile or impotent (Wikipedia Contributors 2018:online). Surrogacy is commercial if the surrogate receives money for carrying a pregnancy; it is altruistic 'if she receives no compensation beyond reimbursement of medical and other reasonable expenses' (Wikipedia Contributors 2018:online). There are two forms of surrogacy, namely traditional surrogacy and gestational surrogacy. Traditional surrogacy is the type in which the 'surrogate mother is inseminated with the semen of the commissioning father or donor sperm', in which case she is biologically the mother of the baby (Umeora et al. 2014:online). Gestational surrogacy is that in which the surrogate mother makes no genetic contribution to the foetus. In this case, pregnancy is the result of in vitro fertilisation (IVF), which 'literally means the fertilization of eggs with sperm in glass, which translates to fertilization outside of the body in the laboratory' (Dominion Fertility 2018:online). To put it in another way, in traditional surrogacy:

[F]ertilization occurs inside the woman [whereas] for IVF testtube babies are developed from an egg that was fertilized outside the body, and then implanted in the uterus of the biological or surrogate mother. (Best Fertility Clinics:online)

Hence, in a way, 'traditional surrogacy' has been correctly used by some writers to describe Hagar's function in Genesis 16 , possibly 'one of the earliest recorded cases of surrogacy' (Lyons 1987; cf. Information on Surrogacy 2016:online). Hagar performed the role of a surrogate mother in using 'her own egg in the child she's carrying for intended parents' (Surrogate.com 2009:online). That is to say that in modern times, Sarai need not have shared her husband sexually with Hagar; rather the latter would simply have been artificially inseminated with Abram's semen, and she would carry the pregnancy for him and Sarai and deliver the baby to the couple at birth. In this way, a childless African couple finds solace in the Hagar narrative with the suggestion of surrogacy as a pragmatic solution to their problem.

In view of the ancient Near Eastern customs earlier discussed, Hagar was only one of the many cases of surrogacy in antiquity, but this form of:

$[T]$ raditional surrogacy remained a taboo topic up until the twentieth century ... [because, among other stigmas] surrogate pregnancies would have been conceived naturally - which would be shameful for married couples'; hence, the need for the development of modern surrogacy. (Surrogate.com 2009:online; cf. Information on Surrogacy 2016:online)

Several 'developments in medicine, social customs, and legal proceedings worldwide paved the way for modern surrogacy', particularly in the 1970s (Wikipedia Contributors 2018:online). In 1978 Louise Brown, the first 'test-tube baby', was born in England, 'the product of the first successful IVF procedure' (Wikipedia Contributors 2018:online; cf. Surrogate.com 2009:online). Traditional surrogacy came to a head in 1984-1986 with the case of Baby M in the State of New Jersey, US. In this controversy:
Bill and Betsy Stern hired Mary Beth Whitehead to be their surrogate in 1984, agreeing to pay her \$10 000. Whitehead's eggs were used in the artificial insemination process, making her the biological mother of the child. When the baby was born and it was time for Whitehead to sign over her parental rights, she refused and took custody of baby Melissa Stern ('Baby M.') starting a long custody battle in 1986.... [At the end] the New Jersey Supreme Court ruled that the surrogacy agreement between Whitehead and the Sterns was illegal and, therefore, restored Whitehead's parental rights. Custody was granted to Bill Stern, with Whitehead receiving visitation rights. (Surrogate. com 2009:online; cf. Umeora et al. 2014:online)

At present, worldwide:

$[P]$ oor regulatory frameworks are still the norms, with only 71 nations having any surrogacy laws whatsoever ... Only a handful of countries around the world have laws legalizing commercial surrogacy, which are essentially a requirement for surrogacy agencies to set up shop. (Glaser 2016:online)

In the US, for example, 'legislation and legality of surrogacy varies from state to state' (Umeora et al. 2014:online; Wikipedia Contributors 2018:online). In England it 'is banned by the Surrogate Amendment Act of 1985'. It is also illegal in Sweden, Finland, Japan, Saudi Arabia, and China (Umeora et al. 2014:online). In 'the developing nations, surrogacyrelated regulatory structures are messy if they exist at all' (Glaser 2016:online; cf. Wikipedia Contributors 2018:online). In the African continent, it is only South Africa that has laws governing commercial surrogacy (Wikipedia Contributors 2018:online); in other countries, none exists at all, to the best of our knowledge. In Nigeria, for instance, after the birth of the first test tube baby in 1989, 'there was no follow-up in this field until a few years ago with the establishment of some private IVF clinics' mostly in the southwestern commercial city of Lagos. And, it is important to mention that there are no regulatory bodies at all that license or monitor the activities of these fertility clinics (Omo 2018:online).

However, even when it is legally regulated, commercial surrogacy will still face many challenges in Africa, particularly from the perspective of cultural traditions relating to pregnancy, childbirth and blood relationship. In many parts of Africa pregnancy and childbirth are highly celebrated. A pregnant woman moves about with joy with her protruded tummy, and the whole community awaits her day of delivery. In commercial surrogacy where a surrogate has to be hired to carry pregnancy, this enthusiasm of openly carrying pregnancy and joyfully awaiting delivery is absent for the intended parents; hence even when the surrogate mother delivers the baby to them, rather than being joyful they may, in fact, feel ashamed because of suddenly having children when no one saw pregnancy. Hence, the intended parents still feel unfulfilled, and do not really see themselves as real parents. Moreover, to many around the globe, not only in Africa, 'the idea of paying a woman to carry a child seems abhorrent,' not only to the intended parents but especially to 
the surrogate mother (Glaser 2016:online). Hence, in most parts of Africa today, surrogate mothers would still be seen by many as child sellers, and '... may be culturally and socially stigmatized ... [and] may be forced into social isolation' (Umeora et al. 2014:online). The concept of blood relationship is very strong in Africa in which there is:

$[A]$ vertical conception of family that dates back to ancestry and projects into the future ... [comprising] ancestors, the present generation and the unborn, all blood related in an unbroken sequence. (Umeora et al. 2014:online)

This conception of lineage does not envisage surrogate children; hence a child born via commercial surrogacy may suffer segregation not only by the other children in the family but, in fact, by the members of the lineage and the community at large. As Umeora et al. (2014) put it:

Commercial surrogacy threatens the sanctity of this lineage and changes the way children are valued, from being loved and valued by their parents and others to being used as the case may be, as an object of commercial profit-making. (Umeora et al. 2014:online)

Another problem with commercial surrogacy is the cost, especially for those Africans of low social economic status, who of course are in the large majority. Philpott (2013) states that 'the costs for surrogacy range from $\$ 40,000$ to $\$ 140,000$ ' (Philpott 2013:online), whereas McBrian (2015) puts it at $\$ 100000$ to $\$ 150000$.

Yet, surrogacy would have several benefits for African couples who cannot have their own children by themselves. 'The World Health Organization reports that one in five couples in the world have infertility' (Fertility Hub Nigeria 2017:online), while experts say 'that more than 30 percent of women [in Africa] are unable to have children' (NBCNEWS 2018:online). As earlier mentioned, for those with 'infertility and those with medical conditions that make pregnancy unsafe, surrogacy is often the answer to years of unsuccessful attempts to create a family' (Southern Surrogacy 2018:online). For example, 'surrogacy is often perceived as the only option when women have a damaged uterus, or have lost their uterus to diseases such as cancer' (Health24 2012:online). As Umeora et al. (2014) rightly conclude:

Surrogacy arrangement is deemed by many as advantageous given the dearth of children available for adoption and complexity of qualifying as adoptive parents. It may represent the only hope for some infertile couple to raise a family. (online)

\section{Conclusion}

This research acknowledged the findings of the historicalcritical method on the patriarchal narratives, but employed a reader-oriented approach to study the marriage of Hagar to Abram. Some scholars have given this text a sexual exploitation interpretation, describing Hagar as a victim of rape or sex trafficking. Reappraising this view against the social background of the text, we found out that, rather the Abram-Hagar union is better understood as legitimate surrogacy. The research also found out that the desire for children is as strong in African culture as it was in ancient Israel; hence, as against the claim of sexual abuse, the text appeals to the African reader in the context of the problem of childlessness. In the traditional African context, Hagar is understood as a second wife whom Abram had to marry on account of Sarai's barrenness. In modern times, she can be seen as a surrogate engaged by the Abram family; hence the childless African couple also finds the Hagar narrative as suggestive of surrogacy for their problem. Although surrogate motherhood would find some challenges in African culture in the areas of pregnancy, childbirth and blood relationship, it still can be the means by which certain African couples may raise their own families. Unfortunately, today in the whole of Africa it is only South Africa that has laws governing surrogacy. However, in view of its enormous benefits for many who are being denied the joy of parenthood owing to sterility, other countries are enjoined to make regulations that would allow and monitor the activities of competent individuals or groups to operate the business of surrogate motherhood.

\section{Acknowledgement Competing interest}

The author has declared that no competing interests exist.

\section{Author contributions}

I declare that I am the sole author of this research article.

\section{Ethical consideration}

This article followed all ethical standards for carrying out research without direct contact with human or animal subjects.

\section{Funding}

This research received no specific grant from any funding agency in the public, commercial, or not-for-profit sectors.

\section{Data availability statement}

Data sharing is not applicable to this article as no new data were created or analysed in this study.

\section{Disclaimer}

The views and opinions expressed in this article are those of the authors and do not necessarily reflect the official policy or position of any affiliated agency of the authors.

\section{References}

Abasili, A.I., 2011, 'Seeing Tamar through the prism of African woman: A contextual reading of Genesis 38', Old Testament Essays 24(3), 555-573.

Adamo, D.T., 2005, 'The African wife of Abraham', Old Testament Essays 18(3), $455-471$.

Ademiluka, S.O., 2003, 'The impact of Christian missionary activity on the sociocultural heritage of the Okun Yoruba', in A. Olukoju, Z.O. Apata \& O. Akinwumi (eds.), Northeast Yorubaland: Studies in the history and culture of a frontier zone, pp. 134-142. Rex Charles, Ibadan. 
Ademiluka, S.O., 2007, 'A study of the patriarchal narratives (Genesis 12-50) in an African setting', Old Testament Essays 20(2), 273-282.

Albright, W.F., 1961, 'Abraham the Hebrew: A new archaeological interpretation', BASOR 163(1961), 36-54. https://doi.org/10.2307/1355773

Alt, A., 1966, 'The God of the Fathers', in A. Alt (ed.), Essays on Old Testament history and religion, pp. 50-93. Eng. Trans, Blackwell, Oxford.

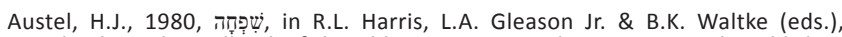
Theological Wordbook of the Old Testament, 2 vols, p. 946. Moody Publisher Chicago, IL.

Best Fertility Clinics and Costs of IVF in Nigeria, viewed 21 June 2018, from https:// www.bukasblog.com.ng.

Bible Hub 2004-2017a, Commentary on Genesis 16:2, viewed 04 June 2018, from http://biblehub.com/commentaries/genesis/16-2.htm.

Bible Hub 2004-2017b, Commentary on Genesis 30:1, viewed 03 June 2018, from http://biblehub.com/commentaries/genesis/30-1.htm.

Bible Hub 2004-2017c, Commentary on 1 Samuel 1:6-7, viewed 03 June 2018, from http://biblehub.com/commentaries/1_samuel/1-6.htm

Birch, B.C., Brueggemann, W.F., Terence, E. \& Petersen, D.L. (eds.), 2005, A theological introduction to the Old Testament, 2nd edn., Abingdon, Nashville, TN.

Bright, J., 1981, A history of Israel, The Westminster, Philadelphia, PA.

Bvukutwa, G., 2014, Gender equality is not a western notion, viewed 09 January 2018, from https://tinyurl.com/y8vy6frb.

Dominion Fertility, 2018, What is fertility and how is it performed?, viewed 13 May 2018, from https://www.dominionfertility.com/fertility-treatment-faq/46-whatis-ivf-and-how-is-it-performed/.

Emenusiobi, M.R., 2013, Africa: A continent of love for life and children, viewed 20 June 2018, from http://maryrosanna4life.blogspot.com/.

Encyclopaedia Judaica, 2008, Barrenness and fertility, viewed 02 June 2018, from http://www.jewishvirtuallibrary.org/barrenness-and-fertility.

Fertility Hub Nigeria, 2017, A comprehensive ranking of fertility clinics in Nigeria, viewed 20 June 2018, from https://www.fertilityhubnigeria.com/comprehensiveranking-fertility-clinics-nigeria/.

Feyerabend, K., 1959, Langenscheidt's Hebrew-English dictionary. London: Methuen $\&$ co.

Fletcher, E., 2006, Hagar, Sarah's Egyptian slave, viewed 10 May 2018, from http:// www.womeninthebible.net/women-bible-old-new-testaments/hagar/.

Freyhauf, M.S., 2012, Hagar: A portrait of a victim of domestic violence and rape, viewed 24 May 2018, from https://feminismandreligion.com/2012/01/26/hagara-portrait-of-a-victim-of-domestic-violence-and-rape/.

Gertz, J.C., Berlejung, A., Schmid, K. \& Witte, M., 2012, T\&T Clark handbook of the Old Testament, T\&T Clark Int'l, London.

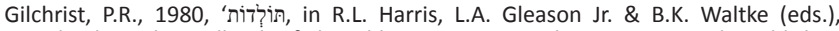
Theological Wordbook of the Old Testament, 2 vols, p. 380. Moody Publisher, Chicago. IL.

Glaser, J., 2016, Womb for rent: Regulating the international surrogacy market viewed 20 June 2018, from http://www.brownpoliticalreview.org/2016/11/ womb-for-rent-regulating-international-surrogacy-market/.

God's Design - Perth, 2016, Hagar and the 'God who sees me' (Part 2), viewed 24 May 2018, from https://godsdesignperth.org/2016/02/28/hagar-and-the-god-whosees-me-part-2/.

Grabbe, L.L., 2007, Ancient Israel: What do we know and how do we Know it?, T\&T Clark, New York.

Graybill, R., 2018, Teaching about sexual violence in the Hebrew Bible, viewed 25 January 2018, from https://tinyurl.com/yd9s887q

Gunkel, H., 1901, The legends of Genesis, Shocken, New York.

Health24, 2012, Surrogacy: The truth, viewed 10 June 2018, from https:// www.health24.com/Parenting/Fertility/About-fertility/Surrogacy-the-truth20120721.

Igbelina-Igbokwe, N., 2013, Contextualizing gender based violence within patriarchy in Nigeria, viewed 29 January 2018, from https://tinyurl.com/ycmmoy2g.

Information on Surrogacy, 2016, History of surrogacy - Surrogacy stories throughout time, viewed 16 June 2018, from http://information-on-surrogacy.com/history-of surrogacy.

Jamieson, R., 2018, The first book of Moses, called Genesis, viewed 24 May 2018, from https://www.biblestudytools.com/commentaries/jamieson-fausset-brown/ genesis/genesis-16.html.

Joseph, A., 2017, The handmaid's tale as a legitimate reading of Genesis?, viewed 09 May 2018, from https://shiloh-project.group.shef.ac.uk/?p=1571.

Klein, J.M., 2008, Why scholars just can't stop talking about Sarah and Hagar, Viewed 09 May 2018, from https://www.usnews.com/news/religion/articles/2008/01/25/ why-scholars-just-cant-stop-talking-about-sarah-and-hagar.

Klopper, F., 2010, 'Rape and the case of Dinah: Ethical responsibilities for reading Genesis 34', Old Testament Essays 23(3), 652-665.

Longman, T. \& Dillard, R.B., 2006, An introduction to the Old Testament, Zondervan, Grand Rapids, MI.
Lyons, R.F., 1987, 'Surrogate motherhood should be privatized; biblical precedents', The New York Times, viewed 19 May 2018, from https://www.nytimes.com/1987/03/03/ opinion/l-surrogate-motherhood-should-be-privatized-biblical-precedents214487.html.

Mann, T.W., 2011, The book of the former prophets, James Clarke \& Co, Cambridge.

Marriage and the Family in Africa, 1988, viewed 10 June 2018, from http://www. cormacburke.or.ke/node/288.

Matthews, V.H., 2002, A brief history of ancient Israel, WJK, Louisville, KY.

Mbiti, J.S., 1969, African religions and philosophy, Heineman Educational Books, London.

McBrian, W., 2015, 5 Pros of Surrogacy, viewed 18 June 2018, from https://www. circlesurrogacy.com/blog/circle-surrogacy/5-pros-surrogacy/.

McComiskey, T.M., 1980, השָָׁ, in R.L. Harris, L.A. Gleason Jr. \& B.K. Waltke (eds.) Theological wordbook of the Old Testament, 2 vols, p. 60. Moody Publisher, Chicago, IL.

McGrath, J.F., 2012, Hagar as woman, slave and wife, viewed 24 May 2018, from http://www.patheos.com/blogs/religionprof/2012/10/hagar-as-woman-slaveand-wife.html.

Moore, M.B. \& Kelle, B.E., 2011, Biblical history and Israel's Past, WmB. Eerdmans, Grand Rapids, MI.

NBCNEWS.com, 2018, \$200 in vitro? Doctors to offer procedure in Africa, viewed 20 June 2018 , from $\mathrm{http} / / /$ www.nbcnews.com/id/25573669/ns/health-pregnancy/ t/in-vitro-docs-offer-procedure-africa/\#.Wyp9GcXZ_k

Noll, K.L., 2013, Canaan and Israel in antiquity: A textbook on history and religion, T\&T Clark, New York.

Noth, M., 1950, Geschichte Israels, Vandenhoeck \& Ruprecht, Gottingen.

Omo, F., 2018, IVF clinics in Nigeria, viewed 21 June 2018, from https://www.izito.ng/ ws?q=fertility $\% 20$ clinic $\% 20 \mathrm{in} \% 20$ nigeria\&asid=iz_ng_gb_1_cg1_10\&mt=b\&nw= $\mathrm{s} \& \mathrm{de}=\mathrm{c} \& \mathrm{ap}=1 \mathrm{t} 2$

Oshadare, O.T., Audu, M.S., Okiri, G.W. \& Akor, L.Y., 2005,Perspectives on Nigerian peoples and culture, Aboki, Makurdi.

Philpott, S., 2013, Weighing the options between adoption and surrogacy, viewed 16 June 2018, from https://mom.me/kids/7325-weighing-options-betweenadoption-and-surrogacy/.

Religious Tolerance, 2018, "Passages in the Hebrew Scriptures (Old Testament) that Treat Women as Inferior to Men." viewed 22 January 2018, from https://tinyurl.com/b7dv9.

Roth, C.A., 2016, Hagar, wife and slave, viewed 24 May 2018, from https:// obscurecharacters.com/2016/09/04/hagar-wife-and-slave/.

Scott, J.B., 1980, המד, in R.L. Harris, L.A. Gleason Jr. \& B.K. Waltke (eds.), Theological wordbook of the Old Testament, 2 vols, p. 49, Moody Publisher, Chicago, IL.

Smith, C.D., 2018, Chuck Smith bible commentary, viewed 11 March 2018, from https://tinyurl.com/y9ctcja8.

Southern Surrogacy, 2018, The challenges and rewards of surrogacy for everyone involved, viewed 18 June 2018, from https://southernsurrogacy.com/surrogacyinformation/the-challenges-and-rewards-of-surrogacy-for-everyone-involved/.

Sex, Slavery and Surrogacy, 2009, The story of Hagar, viewed 10 May 2018, from https://subrosa09.wordpress.com/2009/05/21/sex-slavery-and-surrogacy-thestory-of-hagar/.

Surrogate.com, 2008, From the bible to today: The history of surrogacy, viewed 10 May 2018, from https://surrogate.com/about-surrogacy/surrogacy-101/historyof-surrogacy/.

Thompson, T.L., 1974, The historicity of the patriarchal narratives: The quest for the historical Abraham, De Gruyter, Berlin.

Umeora, O.J., Umeora, M.C., Emma-Echiegu, N.B. \& Chukwuneke, F.N., 2014, 'Surrogacy in Nigeria: Legal, ethical, socio cultural, psychological and religious musings', African Journal of Medical and Health Sciences, viewed 10 June 2018 musings, African Journal of Medical and Health Sciences, viewed 10 June 2018, from $\mathrm{http}: / /$ www.ajmhs. org/article.asp?issn=238

Van Seters, J., 1975, Abraham in history and tradition, Yale University Press, New Haven, CT.

Waltke, B.K., 1980, wordbook of the Old Testament, 2 vols, pp. 116-118, Moody Publisher, Chicago, IL.

Webber, C.P., 1980, הָגָר, in R.L. Harris, L.A. Gleason Jr. \& B.K. Waltke (eds.), Theologica wordbook of the Old Testament, 2 vols, p. 206. Moody Publisher, Chicago, ILO.

Weems, R.J., 2005, A mistress, a maid and no mercy: Understanding the timeless connection between women of today and women in the bible, Warner Books, New York, viewed 10 May 2018, from https://subrosa09.wordpress.com/2009/05/21/ sex-slavery-and-surrogacy-the-story-of-hagar/.

Wellhausen, J., 1994, 'Israel', in Prolegomena to the history of Israel, pp. 429-548, Scholars, Atlanta, GA.

Wenham, G.J., 1994, 'Genesis', in D.A. Carson, G.J. Wenham, J.A. Motyer \& R.T. France (eds.), New Bible Commentary, 4th edn., pp. 54-91, IVP, Nottingham.

Wenham, G.J., 2006, Sex and violence in Genesis, viewed 10 May 2018, from http:// www.jubilee-centre.org/sex-violence-genesis-gordon-wenham/.

Wikipedia Contributors, 2018, Surrogacy, viewed 18 June 2018, from https://en. wikipedia.org/wiki/Surrogacy. 